\title{
Editor's highlight for TSAF D-17-00396: carbon and oxygen isotopes in tree rings-climate signals and microsite effects
}

\author{
Arthur Gessler ${ }^{1,2}$ D \\ Received: 21 February 2018 / Accepted: 26 February 2018 / Published online: 3 March 2018 \\ (c) Springer-Verlag GmbH Germany, part of Springer Nature 2018
}

\begin{abstract}
Key message Isotopes are important proxies in tree rings but microsite differences are often not taken into account. Esper et al. (Trees 32:1-15, 2018) assessed microsite differences contributing to the understanding of local drivers. Abstract Carbon and oxygen isotopes are important proxies in tree ring archives that allow the reconstruction of the past climate as well as to retrospectively assess tree responses towards climatic drivers Esper et al. (Trees 32:1-15, 2018, this issue) took into account potential microsite differences as they not only chose a strong latitudinal gradient in Sweden (Kiruna, north of the polar circle vs. Stockholm) but also collected at both locations tree rings from Pinus sylvestris that grew directly at a lakeshore and trees up to $30 \mathrm{~m}$ upslope.
\end{abstract}

Keywords Tree ring $\cdot$ Isotope $\cdot$ Local site conditions

Carbon and oxygen isotopes are important proxies in tree ring archives that allow the reconstruction of the past climate (e.g. Kress et al. 2010; Treydte et al. 2006) as well as to retrospectively assess tree responses towards climatic drivers (e.g. Jansen et al. 2013). Stable isotopes analyses complement the assessment of more classical tree ring parameters such as tree ring width or maximum latewood density and might be more closely linked to tree physiology (c.f. Gessler et al. 2014) compared to the growth-related patterns. However, the exact physiological signal that is conveyed by tree ring isotopes is difficult to be straightforwardly disentangled. Whilst the fractionation mechanisms during photosynthesis that lead to the carbon isotopic signature $\left(\delta^{13} \mathrm{C}\right)$ of new assimilates are well understood (Farquhar et al. 1982), postcarboxylation discrimination and mixing of various carbon pools might partially uncouple tree ring $\delta^{13} \mathrm{C}$ information from photosynthesis and its climatic drivers (Offermann et al. 2011; Tcherkez et al. 2007). For the oxygen isotope

Communicated by A. Gessler.

Arthur Gessler

arthur.gessler@wsl.ch

1 Forest Dynamics, Swiss Federal Research Institute WSL, Birmensdorf, Switzerland

2 Institute of Terrestrial Ecosystems, ETH Zurich, Zurich, Switzerland composition $\left(\delta^{18} \mathrm{O}\right)$ of tree rings, the situation is even more complex

On the one hand, variations in $\delta^{18} \mathrm{O}$ of the source water taken up by the tree can contain climatic information since air temperature and water vapor pressure amongst other parameters affect precipitation $\delta^{18} \mathrm{O}$ (Araguás-Araguás et al. 2000). On the other hand, local differences in water access (e.g. river water, ground water) can influence the source water $\delta^{18} \mathrm{O}$ causing differences not necessarily directly related to climate or weather. Moreover, not only the source water isotopic composition but also evaporative oxygen isotope enrichment of leaf water is imprinted on the organic matter produced during photosynthesis (Barbour 2007) and the enrichment is affected by climate (e.g. VPD) as well as by tree physiological processes (e.g. stomatal response and transpiration). If that were not complex enough, various downstream fractionation steps and oxygen atom exchange between tissue water and organic matter occur and their impact on the tree ring $\delta^{18} \mathrm{O}$ might not be constant but variable with environmental divers and physiological processes (Song et al. 2014; Sternberg and Ellsworth 2011).

In conclusion, subtle interactions between climate and tree responses but also site-specific conditions (e.g. access to different water sources) might affect the isotope signals in tree ring series complicating climate reconstructions based on $\delta^{13} \mathrm{C}$ and $\delta^{18} \mathrm{O}$. 
Esper et al. (2018, this issue) took into account the potential microsite differences as they not only chose a strong latitudinal gradient in Sweden (Kiruna, north of the polar circle vs. Stockholm) but also collected at both locations the tree rings from Pinus sylvestris that grew directly at a lakeshore and trees up to 30 meters upslope with no access to lake and phreatic water. The authors could show thateven though there were significant correlations between all stable isotope microsite chronologies- the moist microsites (at the lakeshore) recorded climate signals more intensively than the drier microsites. Access to lake water also lead to a

${ }^{13} \mathrm{C}$ depletion of approx. $1 \%$ most probably due to higher stomatal conductance compared to the drier site whilst $\delta^{18} \mathrm{O}$ was not affected by microsite condition. The results indicate that on the one hand, tree rings from moist microsite habitats might provide advantages for climate reconstructions. On the other hand, they show that it should be avoided to mix moist and dry microsites when producing composite chronologies over long time periods (e.g. millennia) as this might cause temporal differences in the climate reconstruction accuracy.

While the study of Esper et al. is an important step forward in understanding and disentangling regional and local drivers for tree ring $\delta^{13} \mathrm{C}$ and $\delta^{18} \mathrm{O}$, we still need to expand the assessments of the mechanisms determining the isotope composition of tree rings over long time periods. One way to go further ahead might be the intra-annual characterization of stable isotopes in tree rings (e.g. Helle and Schleser 2004) in long time series, which might allow a deeper understanding of the temporal linkages between climatic drivers and isotopic responses. Another promising way to exploit the existing mechanistic knowledge for paleo-environmental studies is the use of inverse modelling. Such approaches allow to take advantage of mechanistic models to derive environmental variables from dendroecological parameters including stable isotopes (Gessler et al. 2014).

Author contribution statement

AG has written the manuscript and done all other analyses related to the manuscript.

\section{Compliance with ethical standards}

Conflict of interest The author declares that he has no conflict of interest.
Human participants and animal rights statement The research did not involve animals or humans.

\section{References}

Araguás-Araguás L, Froehlich K, Rozanski K (2000) Deuterium and oxygen-18 isotope composition of precipitation and atmospheric moisture. Hydrol Process 14:1341-1355

Barbour MM (2007) Stable oxygen isotope composition of plant tissue: a review. Funct Plant Biol 34:83-94

Esper J, Holzkämper S, Büntgen U, Schöne B, Keppler F, Hartl C, St. George S, Riechelmann DF, Treydte K (2018) Site-specific climatic signals in stable isotope records from Swedish pine forests. Trees 32:1-15

Farquhar GD, O' Leary MH, Berry JA (1982) On the relationship between carbon isotope discrimination and the inter-cellular carbon-dioxide concentration in leaves. Aust J Plant Physiol 9:121-137

Gessler A, Ferrio JP, Hommel R, Treydte K, Werner RA, Monson RK (2014) Stable isotopes in tree rings: towards a mechanistic understanding of isotope fractionation and mixing processes from the leaves to the wood. Tree Physiol 34:796-818

Helle G, Schleser G (2004) Beyond CO2-fixation by Rubisco-an interpretation of C-13/C-12 variations in tree rings from novel intra-seasonal studies on broad-leaf trees. Plant Cell Environ 27:367-380

Jansen K, Sohrt J, Kohnle U, Ensminger I, Gessler A (2013) Tree ring isotopic composition, radial increment and height growth reveal provenance-specific reactions of Douglas-fir towards environmental parameters. Trees Struct Funct 27:37-52

Kress A, Saurer M, Siegwolf RTW, Frank DC, Esper J, Bugmann H (2010) A 350 year drought reconstruction from Alpine tree ring stable isotopes. Global Biogeochem Cycles 24:GB2011. https:// doi.org/10.1029/2009GB003613

Offermann C, Ferrio JP, Holst J, Grote R, Siegwolf R, Kayler Z, Gessler A (2011) The long way down-are carbon and oxygen isotope signals in the tree ring uncoupled from canopy physiological processes? Tree Physiol 31:1088-1102

Song X, Farquhar GD, Gessler A, Barbour MM (2014) Turnover time of the non-structural carbohydrate pool influences $\delta^{18} \mathrm{O}$ of leaf cellulose. Plant Cell Environ 37:2500-2507

Sternberg L, Ellsworth PFV (2011) Divergent biochemical fractionation, not convergent temperature, explains cellulose oxygen isotope enrichment across latitudes. PLoS One 6:e28040

Tcherkez G, Ghashghaie J, Griffiths H (2007) Methods for improving the visualization and deconvolution of isotopic signals. Plant Cell Environment 30:887-891

Treydte KS, Schleser GH, Helle G, Frank DC, Winiger M, Haug GH, Esper J (2006) The twentieth century was the wettest period in northern Pakistan over the past millennium. Nature 440:1179-1182 